\title{
A gene encoding a putative GTPase regulator is mutated in familial amyotrophic lateral sclerosis 2
}

S Hadano, C K Hand, H Osuga, Y Yanagisawa, A Otomo, R S Devon, N Miyamoto, J Showguchi-Miyata, Y Okada, R Singaraja, D A Figlewicz, T Kwiatkowski, B A Hosler, T Sagie, J Skaug, J Nasir, R H Brown Jr, S W Scherer, G A Rouleau, M R Hayden \& J-E Ikeda

Nature Genet. 29, 166-173 (2001).

\section{The gene encoding alsin, a protein with three guanine-nucleotide exchange factor domains, is mutated in a form of recessive amyotrophic lateral sclerosis}

Y Yang, A Hentati, H-X Deng, O Dabbagh, T Sasaki, M Hirano, W-Y Hung, K Ouahchi, J Yan, A C Azim, N Cole, G Gascon, A Yagmour, M Ben-Hamida, M Pericak-Vance, F Hentati \& T Siddique

Nature Genet. 29, 160-165 (2001).

The order of appearance of these articles was incorrect. The correct order is indicated above, which reflects the earlier dates of receipt and acceptance of the article by Hadano et al.

\section{A radiation hybrid transcript map of the mouse genome}

P Avner, T Bruls, I Poras, L Eley, S Gas, P Ruiz, M V Wiles, R Sousa-Nunes, R Kettleborough, A Rana, J Morrisette, L Bentley, M Goldsworthy, A Haynes, E Herbert, L Southam, H Lehrach, J Weissenbach, G Manenti, P Rodriguez-Tome, R Beddington, S Dunwoodie \& R D Cox

Nature Genet. 29, 194-200 (2001).

An error was introduced while preparing the paper for press. It occurs in the list of author affiliations on page 194. The correct affiliation Patricia Ruiz is "Centre de Recherche du CHUL, Ste-Foy, Quebec, Canada." rather than ", Ste-Foy, Quebec, Canada". 